\title{
Political Process and Insecurity Among Youths in Oshodi-Isolo Local Government Area, Lagos
}

DOI: https://doi.org/10.47175/rissj.v2i3.269

\section{| Ogunmefun Folorunsho Muyideen ${ }^{1}$ | Oyeyemi Tolulope Evelyn² |}

\author{
${ }^{1}$ Department of Criminology \\ and Security Studies, Chrisland \\ University, Owode, Abeakuta, \\ Ogun State

\begin{abstract}
${ }^{2}$ Department of Psychology, Chrisland University, Owode, Abeakuta, Ogun State
\end{abstract}

${ }^{1}$ folorunshoogunmefun@gmail.com 2oyeyemitolulope55@gmail.com

\begin{abstract}
Political insecurity is an inevitable endemic menace negating human development across most of the developing nations. However, various reviewed publications posits that youths in most of all developing nations are categorized as crime prone segment of the country used by the state political actors for obstructing political process based on their perceived political vested interest. Youths in all human society are known as the catalyst for accelerating and achieving progressive socioeconomic and political development if properly managed otherwise apolitical involvement of the youths in political processes will degenerate to social milieu such as civil unrest, traumatization, retrogressive economic development, death, bad national and international image among the league of nations, Anomie and structural functionalist theories were adopted Qualitative method was adopted for data collection from 40 respondents through the use of In-depth interview and purposive sampling techniques while content method of data analysis was adopted for the transcription of the data collected from the interviewees at Oshodi-Isolo, Lagos. Large numbers of the interviewees concluded that Nigeria political processes, elections, electioneering process is faulty therefore there is a needs for proper reorientation, full sensitization and socialization of Nigerian on the types of political culture and community controlling policing measure needed to foster the growth and development of political process in Nigeria More so, Nigeria youths should purged themselves out of preconceived notion that labeled them (youths) as agent of political violence or insecurity in the country so as to enjoy progressive democratic ethos

KEYWORDS

politics; process; insecurity; youths; development
\end{abstract}

\section{INTRODUCTION}

One of the fundamental tasks expected to be carried out by State functionaries and the Citizens is anchored on the achievement of progressive democratic processes that promote peaceful co-existence among societal members. Scholars such as Oyekanmi and Soyombo (2015); Ritzer (2013); Haralambos \& Holborn (2015); Ninalowo (2012), avers that the growth and development of a State depends largely on the legitimate tasks performed by the State functionary and the Citizens which will determine how semblance of orderliness will be achieved. In addition, in every human society, it is expected that State functionary are established by constitutional and historical laws to provide basic ameliorative incentives such as provision employment opportunities, security to lives and properties among others 
while the citizens are expected to participate in democratic processes as means of obeying national calls or services and pay tax regularly to facilitate semblance of orderliness

Historically, the political process observed today in Nigeria is an upshot of what is learned and gained from the British Administration structure or coercive force. According to Davies (1998), before the advent and adoption of the Western political philosophy, system and structure in Nigeria, the dominant ethnic groups in their various communities (Yoruba, Igbo and Hausa/Fulani) have their own established political process(es) of selecting or electing who will represent their views and images in any political process, symposium, dialogue or system. Prior to the annexation of Nigeria in $18^{\text {th }}$ century and the amalgamation of the Northern and Southern protectorate in 1914, Ajayi and Fashagba (2016) avers that the British are more interested in the amalgamation of the Northern and Southern Protectorate with determination to rule Nigeria as an entity because of her economic advantages in the world. More so, they (British government) introduced Federal arrangement to Nigeria political system due to heterogeneous structure of the ethnic groups found in the country which was later misused by the current political elites in the country for selfish interest, abuse and violation of human rights. For example, Agbu (2016) opines that most Nigerian electorates during, before and after elections believed that their votes do not counts or underrepresented in term of electing who will be their leaders. More so, the political elites after been elected into political positions underrepresent the interest of the electorates who voted them into political offices and tend not to fulfill the political promises stated as slogan before, during and after the election polls.

However, Okoosi-Slimbine (2010) gave a comprehensive assertion on the importance of positive political process in any nation, when he laments that political process comprises of the totality of ways and means of acquiring and exercising governmental authority in a political system of any nations for promoting peaceful coexistence. More so, he argued that it is impossible to build and consolidate progressive democratic governance without an institutionalized legislative arm for the management of the political processes. Evidence gathered from several publications on the political process in the Post-Independence era f1960 till 2020 shows that the current political processes in Nigeria inherited by the political elites is tailored around what is obtainable or learned from the British Administration. This is one of the reasons for Agbu (2016) assertion that the political process in Nigeria needs to be thoroughly studied because of the volatile nature and serious socio-economic and political implications associated with the practices in Nigeria. Thus, the ill-political process activities rooted in Nigeria political system has led to other social vice such as the use of money to ferment intimidation (Adepegba, 2019; Odama, 2019), maiming, killing of perceived opponents, (Premium Times, 2019; Adeniyi, 2016) vandalisation of properties worth millions (Sowole, 2019; Offiong et al, 2016 ) deployment of youths as political thugs (Oladele, Anthony, Sunday \& Ojo, 2019), All these practices will negate quality and meaningful democracy and progressive governance in Nigeria if not monitored or properly investigated

In any countries in the world today, the nature and structure of political process is considered as the pillar for achieving positive democracy and transparent governance in the world (Nnamam, 2014; Yagboyaju, 2015). This is because political process adopted by any country will determine, facilitate and give effect to the right candidate to govern a state by consent of the electorates. In addition, Odama (2019) supported the view by stating that election and political choice enjoyed by the electorates before, during and after election in any country will gives meaning to the right candidate to govern a state by popular consent or as a means for requirement of legitimacy to political offices. According to Jega and Iheanu (2015), Nigeria political process have been labeled as conflict ridden due to several menace 
associated with the practice which negate human and societal development leading to high level of insecurity in the country

According to Yusuf (2014) youth's involvement in insecurity is a serious universal menace negating developmental activities of most of the developing countries. In addition, Nigeria in the past and present had witnessed massive involvements of youth in various forms of violence, although the nature of this violence varies from religious, political or economic based (Adeniyi, 2016). The negative involvement of youths in political conflicts in Nigeria had degenerated to other social vices such as kidnapping, terrorism, psychological trauma, civil unrest, sudden death, retrogressive economy, bad national and international image among others in the print media and other sources of information. The prevalence of political violence in Nigeria have retrogressed developmental activities of the country which in another dimension has really awake and increase human and environmental consciousness of the people in the country.

The political history of the country (Nigeria) from post-colonial period indicated that political violence is a fractional party of the Nigeria democratic System while youths in Nigeria are used and labeled as the major instrument used by the political State Elite to obstruct or clandestine socio-political and economic development of the State (Salami, 2012) But Nayak (2012) demonstrate a contrary or diverse opinion when he laments that it unfair to generalized and labeled all Nigeria youths as violent prone segment of the population. The negative use of the youths in developmental activities in the State influenced Igbo and Ikpa assertion (2013) when they laments that it is unfortunate that youth deviation from the act of practicing ideal political process has become one of the security challenges facing man-kinds in the present Nigeria Reports gathered from scholarly works of the past indicated that large number of Nigerian youths indulged in political vandalism as a result of numerous challenges facing them which include high rate of poverty, increase in unemployment rate, low or lack of adequate and lack of fundamental access to quality education acquisitions among others. These are said to be the factors responsible for this high level of insecurity orchestrated by youth restiveness in the form of bombing mosques, churches, markets and killing of innocent people. The phenomenon of political violence and youth's involvement in insecurity activities has gained its momentum in the study site (Oshodi-Isolo local Government). Thus, the study site is known as one of the notorious environ in Lagos state where large number of youths indulged in political violence before, during and after elections leading to loss of lives, vandalisation of properties, civil unrest and psychological problems among the societal members. It is on this ground the following set objectives were structured to guides the principles governing the research outcome

a) what are the predisposing factors that lead to political insecurity in Nigeria Election

b) How has political party formation influence political violence during election among various political actors

c) To what extent has the Nigeria Police strive to curb the situation of political thuggery during in Oshodi-Isolo Local Government Area, Lagos

d) What is the social cost of political insecurity among various institutions in the study locations

\section{LITERATURE REVIEW}

\section{Theory of Alienation}

The theory of alienation is drawn from Karl Marx opinion on how people are cut off in any form of developmental activities. According to Ritzer (2013), the estrangement of lower class in any state will led to social disorganization. He argues that for any country to observed and experienced progressive development there must be mutual agreement and 
cooperation between the upper and lower classes in moving the nation forward progressive development socially, economically, educational and psychologically. Thus, when developmental plans are restricted in the hands of the leaders, the followers will feel exempted from active participation. However, such situation will lead to retrogressive development caused mainly by the upper class at the detriment of the lower class in any society. This is mutual process of political or any other forms of developmental plans should be carried out by both the lower and upper classes.. To Marx, the success of political system or political processes should be between the lower and upper classes in terms of decision making before, during and after political processes. He argued that the upper class are the political elite that will seek for the sovereignty or vote of the people before they are elected into political positions as their part of fulfilling their historical and constitutional responsibility on the other hands, the upper class elected are expected to enact policies that will promote quality wellbeing of the masses in terms of acquiring ameliorative incentives and safety standard in the country. Karl argued that semblance of orderliness is obtainable at abstraction level but in reality stage, semblance of orderliness are majorly undermined because of the fact that the lower class are cut off from decision making in the State, cut off from self-participation in governmental activities due to the fact that their vote are perceived to be less recognize in term of decision making on who to represent their views and less or underrepresented in developmental activities because of the selfish interest of the upper class. In relation to Nigeria, one of the major reasons for youths involvement in political violence and insecurity activities is that they are unemployed, underemployed and felt that once the political elites get into political position, they easily forget all the promises made and turn out to rely on their vested interest at the detriment of the general interest of the entire population in the country. The Nigeria situation shows that the youths are marginalized in developmental activities due to the vested interest but still later integrated into negative political participation for destruction of lives and properties which will undermine developmental activities and political process in Nigeria.

\section{Social Contract Theory}

Social contract theory is rooted to several scholars notable among them are Thomas Hobbes, John Locke, Auguste Comte Frederich Hegel and Karl Marx among others (Haralambos and Holborn, 2013; Ritzer, 2012). Thus, the fundamental postulation of the social contract theorists is anchored on bi-lateral and multi-lateral agreement between parties involved in developmental activities based on value consensus. The theorists opine that the social contract or the level of this agreement will determine the level of social development that may occurs in the society. For example, Oyekanmi and Soyombo (2015) argues that for any countries or states in the universal to achieve progressive development and growth the relationship between the Political state functionaries, the public bureaucracy and the citizens must be in positive accords. Thus, the historical and constitutional responsibility of the state and its functionaries is to enact public oriented laws that will promote the wellbeing of the masses in terms of security to lives and properties, creation of quality education, employment opportunities, quality education, accessible loans, good transportation system, quality medical treatment and facilities, quality road network, good insurance policies, conducive working environment among others. In the other dimension, the citizens are expected to pay taxes regularly to the government to enhance and provide all the basic amenities for their usage and also obey national calls or services at any time needed in the country. It is generally agreed that when the bi-lateral or multi-lateral relationship plays their key roles in the social order it will lead to semblance of orderliness but when one of the players especially the government and its functionary failed from performing their historical responsibility in 
the social development, the situation will retrogress the growth and development of the nation. In relations to the topic under consideration, it is the duty and responsibility of the state government and its functionaries to provide a secure political environment, ethos, principles and structure that will promote not hinder the political process in the country. More so, the citizens are expected to be a law abiding citizens before, during and after elections. In Nigeria as at today, youths in Nigeria are largely integrated in to political violence and insecurity activities in the countries due to several challenges facing them. This was supported by Agbu (2016) assertion that the political process in Nigeria needs to be thoroughly studied because of the volatile nature and serious implications associated with the practices in the country. The political states actors or elite understand the game and decided to use the youths as agent of political and economic destruction in the state for their selfish interest.

\section{RESEARCH METHODS}

The importance of methodology in any research inquiry cannot be relegated to the background because it remains the practical plan of actions that a researcher must design in order to achieve the research set goals and objective of the research outcome. Thus, this research work is anchored on the use of both primary and secondary sources of gathering information for the justification of the inquiry. The secondary information is gathered from reviewing various publications relating to the topic under consideration such as journals, articles, textbooks, newspapers among others while the primary source of gathering data through the use of qualitative method. Thus, qualitative data was collected from 40 (forty) respondents through in-depth interviews. After coding, editing and screening thirty-eight (38) of the responses collected were found useful for the explanation of the inquiry. Descriptive research design was adopted with the use of tape recorder (Semi-structure questionnaire) to collect information from the residents of Oshodi-Isolo Local Government Area of Lagos in their various wards, streets and houses to ensure scientific solutions. Nonprobability sampling technique was adopted (Purposive sampling technique) to collect information from the respondent while all ethical consideration such as informed consent, confidentiality and emotional neutrality were all observed and thematic method of data analysis and interpretation was adopted in the validation of the research inquiry so as to bring about policy formulation on peaceful co-existence among the diverse political parties and electorates within Nigeria Political circuit

\section{RESULTS AND DISCUSSION}

This section is centered on the analysis of various socio-demographics information collected from various participants in the two selected communities. Thus, 22 respondents participated and their socio-demographics characteristics were explains as follows

\begin{tabular}{|c|c|c|c|}
\hline \multicolumn{4}{|c|}{ Socio-demographics Characteristics of the Participants on the Field } \\
\hline 1) & Age of the respondents & Frequency & Percentages \\
\hline & a) Less than 20 years & 2 & 5.3 \\
\hline & b) $21 \mathrm{yrs}-25$ years & 5 & 13.2 \\
\hline & c) $26 y r s-30$ years & 13 & 34.2 \\
\hline & d) $31 \mathrm{yrs}-35$ years & 2 & 5.3 \\
\hline & e) $36 y r s-40$ years & 12 & 31.6 \\
\hline & f) $41 \mathrm{yrs}-45$ years & 3 & 7.9 \\
\hline & g) $46 y r s-50$ years & 1 & 2.6 \\
\hline & h) 51years and above & - & - \\
\hline
\end{tabular}




\begin{tabular}{|c|c|c|c|}
\hline Total & & 38 & 100.0 \\
\hline 2) & Sex & Frequency & Percentages \\
\hline a) & Male & 23 & 60.5 \\
\hline b) & Female & 15 & 39.5 \\
\hline Total & & 38 & 100.0 \\
\hline 3) & Religious Affiliation & Frequency & Percentages \\
\hline a) & Christians & 17 & 44.7 \\
\hline b) & Muslims & 20 & 52.6 \\
\hline c) & Traditional Worshipper & 1 & 2.6 \\
\hline d) & Others Specify & - & - \\
\hline Total & & 38 & 100.0 \\
\hline 4) & Level of Education & Frequency & Percentages \\
\hline a) & No formal Education & 8 & 21.1 \\
\hline b) & Vocational skill & 16 & 42.1 \\
\hline c) & Primary education & - & - \\
\hline d) & Junior Secondary Education & - & - \\
\hline e) & Senior Secondary School educa & ation 8 & 21.1 \\
\hline f) & ND/HND/University Educatior & n 4 & 10.5 \\
\hline g) & Professional qualification & 2 & 5.2 \\
\hline h) & Others Specify & - & - \\
\hline Total & & 38 & 100.0 \\
\hline 5) & Marital Status & Frequency & Percentages \\
\hline a) & Married & 21 & 55.3 \\
\hline b) & Singled & 10 & 26.3 \\
\hline c) & Widowed & - & - \\
\hline d) & Divorced & - & - \\
\hline e) & Separated & 7 & 18.4 \\
\hline f) & Others Specify & - & - \\
\hline Total & & 38 & 100.0 \\
\hline 6) & Ethnic Background & Frequency & Percentages \\
\hline a) & Yoruba & 16 & 42.1 \\
\hline b) & Igbo & 19 & 50.0 \\
\hline c) & Hausa/Fulani & 1 & 2.6 \\
\hline d) & Others Specify & 2 & 5.3 \\
\hline Total & & 38 & 100.0 \\
\hline 7) & Wards & Frequency & Percentages \\
\hline a) & Ward A & 5 & 13.2 \\
\hline b) & Ward $\mathrm{C}$ & 2 & 5.2 \\
\hline c) & Ward E & 6 & 15.8 \\
\hline d) & Ward $\mathrm{G}$ & 5 & 13.2 \\
\hline e) & Ward I & 7 & 18.4 \\
\hline f) & Ward $\mathrm{K}$ & 5 & 13.2 \\
\hline g) & Ward M & 5 & 13.2 \\
\hline h) & Ward $\mathrm{O}$ & 3 & 7.8 \\
\hline Total & & 38 & 100.0 \\
\hline 8) & Voters Residence & Frequency & Percentages \\
\hline a) & The same locality & 32 & 84.2 \\
\hline b) & Out of the locality & 6 & 15.8 \\
\hline Total & & 38 & 100.0 \\
\hline 9) & Occupation & requency & Percentages \\
\hline a) & No Employment & 4 & 10.5 \\
\hline b) & Clergyman & 1 & 2.6 \\
\hline c) & Trader/Businessman & 20 & 52.6 \\
\hline d) & Civil Servants & 10 & 26.3 \\
\hline
\end{tabular}




\begin{tabular}{||cccc|}
\hline e) & Others Specify & 3 & 7.9 \\
Total & 38 & 100.0 \\
10) Choice of Political party & Frequency & Percentages \\
a) & Peoples Democratic Party & 11 & 28.9 \\
b) & All Progressive Party & 18 & 47.4 \\
c) & Alliance for Democracy & 2 & 5.3 \\
d) Accord Party & 3 & 7.9 \\
e) & Others Specify & 4 & 10.5 \\
Total & 38 & 100.0 \\
11) Nationality & Frequency & Percentages \\
a) Nigerian & 34 & 89.5 \\
b) & Foreigners & 4 & 10.5 \\
Total & & 38 & 100.0 \\
\hline
\end{tabular}

Source---Field work Reports January, 2020

\section{Socio-Demographic Characteristics of The Participants}

The result gathered from the respondents in their various wards and streets in Oshodi-Isolo Local Government Area of Lagos on socio-economic characteristics of the participants are explained as follows. The result gathered from the first table on the age distribution of the respondents deciphers that $13(34.2 \%)$ of the participants were under the ages of 26yrs-30yrs, $12(31.6 \%)$ of them were under the ages of 36yrs-40yrs, $5(13.2 \%)$ of them were under the ages of $21 \mathrm{yrs}-25 \mathrm{yrs}$ as at the time the research was conducted, $3(7.9 \%)$ of them fall under the ages of $41 \mathrm{yrs}-45 \mathrm{yrs}, 2(5.3 \%)$ of the participants were equally recorded at the ages of less than 20yrs and between 31 yrs-35yrs category 1(2.6\%) of the participant fall under the age bracket of 46yrs-50yrs while nothing was recorded in 51yrs age and above. The outcome of the inquiry show that over $80 \%$ of the respondents that participated in the research inquiry were between the ages of $18 \mathrm{yrs}$ to $40 \mathrm{yrs}$ as at the time the research was carried out. The result of the sex distributions indicated that 23(60.5\%) of the participants were male participants while the female counterpart was recorded at $15(39.5 \%)$. The outcome of the inquiry shows that over $60 \%$ of the participants in the field were male because of the cultural stereotype that women are not expected to get much involved in politicking in Nigeria. Also, the result on the religious affiliation of the participants shows that 20(52.6\%) of the participants were Muslims, 17(44.7\%) of them were Christians, 1(2.6\%) of them were recorded as traditional worshiper while nothing was recorded under others specify category. The finding shows that over 50\% of the participants were Muslims in most of the wards and streets where the research was conducted. On the level of education attainment of the participants, 16(42.1\%) acquired vocational skills such as bricklaying, plumbing, electrical and electronics, furnishing among others, $8(21.1 \%)$ of the participants interviewed claimed to have no formal education and Senior secondary school certificate as at the time the research was conducted equally, $4(10.5 \%)$ of them had either ND/HND/B.Sc certificate, $2(5.2 \%)$ of the educational attainment result was recorded under professional educational attainment while nothing was recorded under primary, junior and others specify categories in term of education attainment of the participants. The outcome of the research inquiry shows that large number of the participants were literate and are politically conscious of their political environ. The marital status result gathered shows that $21(55.3 \%)$ of the participants were married as at the time the research was conducted, $10(26.3 \%)$ of them were singled, $7(18.4 \%)$ of them were separated from their partners before the interview was conducted while nothing was recorded under the categories of divorced and widowed. The finding of the result shows that over $50 \%$ of the participants were married as at the time the research 
was conducted in their various wards, streets and houses. In addition, the result gathered from the ethnic background category indicated that 19(50.0\%) of the participants were from Igbo tribe, $16(42.1 \%)$ of them were from Yoruba tribe, 2(5.3\%) of them were recorded under others specify category indicating they are not from the major dominant tribes in Nigeria while $1(2.6 \%)$ of them were recorded under Hausa/Fulani tribe in Nigeria. The outcome of the result shows that despite the fact that the election was conducted in Yoruba state in Nigeria, 59\% of the participants were from Igbo tribe compared with the Yoruba counterparts. More so, on the field wards and streets are randomly selected to shows how various data were collected at each selected wards and streets, thus, the result indicated that Ward I 7(18.4\%) of the participants were interviewed in various streets, 6(15.8\%) of the participants were interviewed at Ward E in different streets, 5(13.2\%) of the participants were equally recorded in Wards, A, Ward G, Ward $\mathrm{K}$ and Ward $\mathrm{K}$ respectively during the data collection period, $3(7.8 \%)$ of the data collected was in Ward O while 2(5.2\%) of the data collected from the participants was collected from Ward C.. The outcome of the inquiry shows that most of the people interviewed really represented their Wards during the time the research was carried out. Result gathered on voters residence shows that $32(84.2 \%)$ of the voters reside in the wards where the voting process took place while $6(15.8 \%)$ of them are not residents of the locality but carry out trading or business activities and voted for the candidate of their choice in the study area. The occupational result indicated that 20(52.6\%) of the participants were traders or businessmen or women, 10(26.3\%) of them were civil servants, $4(10.5 \%)$ have no formal type of employment meaning no any form of employment as at the time the research work was carried out.3(7.9\%) of them were recorded under others specify category (Internet business) while $1(2.6 \%)$ of the participant was recorded as a clergyman during the research fieldwork. The result gathered on the choice of political party affiliation of the participants shows that $18(47.4 \%)$ of the participants were from Peoples Democratic party of Nigeria, 11(28.9\%) of the participant were from All Progressive Party of Nigeria. 4(10.5\%) of the participants were recorded others specify party platform indicating that they are minority parties such as Fresh Party, APGA among others, 3(7.9\%) of them were members of the Accord party of Nigeria While 2(5.3\%) of the participants were members of the Alliance for democracy in Nigeria. The result shows that the two contesting political parties in Nigeria were found wanting in terms of political processes in the country. Finally, 34(89.5\%) of the participants were Nigerians while $4(10.5 \%)$ of them were foreigners but they are dual citizens of Nigeria and Ghana

\section{Qualitative Data Transcription}

Question 1--what are the predisposing factors that lead to political insecurity in Nigeria Election- Evidence gathered from reviews $\mathrm{f}$ past and recent publications indicated that there are several factors that can be held responsible for increase in youth involvement in political violence that led to civil unrest or psychological problems. According to Agbu (2016) the political process in Nigeria needs to be thoroughly studied because of the volatile nature and serious socio-economic and political implications associated with the practices in Nigeria. Adepegba (2019) laments that the causes of ill-political process activities is rooted in Nigeria political system which has led to other social vice such as the use of money to ferment intimidation (Adepegba, 2019), Killing of perceived opponents because of political positions among others with the help of the youths for their personal political advantages, (Premium Times, 2019). In addition the secondary information gathered commensurate with the primary data gathered from the field supported the view of the past scholars but added to the submission already submitted when the view of the 38 respondents interviews claims that 
Respondent 1 -

"There are several factors that can lead to political insecurity in Nigeria.One of the major factors is the introduction of the Nigerian youths in political violence in Nigeria. To be candid election in Oshodi-Isolo Area of Lagos is always of different dimension when it comes to political process in the state. The level of insecurity before, after and during political or election is very dangerous to the extent that people will not want to move out of their houses to vote because of the ways and manners in which these young boys were carrying guns, cutlass and bottles over every polling booths before or during election. The painful part of it is that the so called community elders and political leaders to include Nigeria Police will be looking at them and no positive dimension to prevent the situation will be done immediately. But some minute later the policemen will now come on board to prevent the wounded Nigerians who came outside to perform their fundamental rights in voting the right candidate for the election"

\section{IDI/Woman//Yoruba/45yrs/Ajao Estate//Ward K//2020}

Respondents 2-------

"Most the boys or thugs used to destroy the electoral process are suffering from illiteracy. If not how on earth will you decide to become political thugs for a leader who will not do what you are expecting from them after paying you to kill the right person before or during election in Oshodi-Isolo, Lagos. Look at this, in Oshodi-Isolo we all came out to vote for the candidate of PDP and later the candidate change to APC at the end of the day on the Lagos state Assemble. This shows that they are more interested in themselves and their families immediately they resumed to office. Please people should ask the reason why the commissioner decided to change to APC without the permission of the followers. Youths that allow any political parties to use him or her as political thugs will blame him or herself after the political terms of the leaders. Let be real with ourselves, how many of their children were involved in political thuggery or violence? Please this should sound like percussions to any youths in Nigeria because Nigeria Youths are labeled as agent of political violence. According to Nayak (2014), Nigerian youths are stigmatized as agent of political destruction used to clandestine political processes in Nigeria"

\section{IDI/Man/Igbo/36yrs/Mafoluku Street/Ward D/2020}

The first research questions asked from the thirty-eight (38) respondents indicated that there are several factors that can be held responsible for the growth and involvement of the Nigeria youths in political insecurity. The findings shows that the secondary and primary source of gathering data were of the same value when the outcome correlate at the end of the research work, out of the thirty-eight (38) respondents that participated in the research inquiry $19(50 \%)$ of the respondents avers that the major reasons for the prevalence of political insecurity is as a result of poverty level experienced in Nigeria, 11(28.9\%) of them claims that the high rate of unemployment in Nigeria is responsible for the increase in political insecurity experienced in the country, 6(15.8\%) said increase in political violence or insecurity in Nigeria is related to the selfish interest of the political leaders to get into political position by force or any negative ways while $2(5.3 \%)$ of the participants claims that most youths that join gangs that destroy political process because they want to get recognition or be known as people that can destroy the progress of political process in Nigeria. 


\section{Question 2---How has political party formation influence political violence during election among various political actors?}

Publications reviews show the impact of the British leaders on the colonization process of the country while the primary data negate the review and submission of other scholars from secondary publications. However, most of the participants were of the view that reality should be deliberated on rather than putting blame on the colonial master of the early 18 century. For example, prior to the annexation of Nigeria in $18^{\text {th }}$ century and the amalgamation of the Northern and Southern protectorate in 1914, Ajayi and Fashagba (2016) explains that the British are more interested in the amalgamation of the Northern and Southern Protectorate with determination to rule Nigeria as an entity because of her economic advantages in the world. More so, they (British government) introduced Federal arrangement to Nigeria political system due to heterogeneous structure of the ethnic groups found in the country which was later misused by the current political elites in the country for selfish interest, abuse and violation of human rights. In another dimension, Agbu (2016) supported Ajayi and Fashagba assertion when he explains that most Nigerian electorates during, before and after elections believed that their votes do not counts or underrepresented in term of electing who will be their leaders. More so, the political elites after been elected into political positions underrepresent the interest of the electorates who voted them into political offices and tend not to fulfill the political promises stated as slogan before, during and after the election polls. The view and result derived from the primary data were interpreted in contrary with what is submitted in the secondary source of information. Thus, the primary submission of the participants interviews are stated below;

Respondent 1 -

We should stop blaming the colonial master for the little they have done since over 100 years ago; we should concentrate on what we can do for ourselves to improve our political structures. We all know that the Amalgamation of 1914 is not by our interest but today we are one Nigeria. Are we saying since that period we are still moving by such trend or are the colonial master doing the thuggery or getting into power by force. We should stop deceiving ourselves and move to the next level that will be full of transparency in our electoral process and governance. For example the same white men we blame are still the people we are calling in order to achieve peaceful elections in Nigeria as foreign observers. The Nigeria political leaders are too full of ego and lack human mercy because of getting into position of authority. It is God that can really help us. We should stand on our feet and fight for political process freedom or else we die in suffering and smiling as Great Fela Anikulapo said in his album (beast of no nation). The party formation of the colonial master does not have anything to do with this dispensation for example Late MKO Abiola then was a yoruba man and all the tribes voted for him. To God we still have a lot of them like that in Nigeria but the concept of political killings turns them down from active participation into political process.

\section{IDI/Man//Yoruba/37yrs/Ere-Akari Estate/Ward G//2020}

Respondents 2-------

"The people that lived in Oshodi-Isolo are living witness to what am trying to say. You are free to interview others from my area so that you have people from different ethnic groups that lived here will want to say concerning the question you asked me now. First and foremost we are still behaving as if we are illiterate as at this time and level of globalization and modernization. Everybody is looking for what to do and how to do and achieve it. How do you want me to believe that the problem of the past is what is still affection our political process or causing political problems in Nigeria. Although, 
Professors can be saying that in schools so that our children can have access to the knowledge of the past and present while in schools learning about the history of their home land. Please go and find out this that an Igbo man believes in reality on ground not sorry of the past. The political process of the past is full of violent activities; we know but not as what we are experiencing in Nigeria now Most of the political parties have or organized political thugs that will fight for them and they are paid for it. Once these thugs are arrested in some minutes you will be surprise to see them again in the larger society living in big houses and travelling up and down to different countries in the name of thuggery. How and what messages are we passing on to the next generation or what kind of leaders are we building for the future. Every political party's leaders have their organized political thugs apart from the state security personnel. Please look at the Nigeria Government in all areas of elected or elected positions; you will be surprise on the numbers of thugs on their paying lists in the country"

\section{IDI/Man/Hausa/34yrs/Mafoluku Street/Ward D/2020}

The outcome of the inquiry shows that the inhabitants of the study site were of diverse opinion on how political party formation can bring about political violence in Nigeria. Out of the thirty-eight (38) participants interviewed, twenty-two (22) of the participants said on can party formation bring about $22(57.8 \%)$ of the respondent believed that political party formation as at this dispensation should not bring about destruction of lives and properties of the people like what we have experienced in the past. 8(21.1) of them said what we are experiencing today in Nigeria politics is what we have learn from the said colonial master and that is what we are still experiencing till tomorrow unless if revolution occurs that we take all these so called leaders of selfish interest away while the remaining $8(21.1 \%)$ of them said they do not have anything to say concerning the question but their mind is that the personnel God will send as messiah to save Nigeria out of these political gladiators will come and deliver the entire Nigerians from advanced slavery

\section{Question 3---To what extent has the Nigeria Police curb the situation of political thuggery before, during and after election in Oshodi-Isolo Local Government Area, Lagos}

Political thuggery is one of the major vice destroying the image of the country (Nigeria), nationally and internationally. Although, there are several milieu militating and negating the political security and development of the country (Nigeria), The Nigeria Police cannot do it alone, there is a needs for joint effort in tackling this insecurity issues in the country. This is the reason for Scholars such as Oyekanmi and Soyombo (2015); Ritzer (2013); Haralambos \& Holborn (2012); Ninalowo (2012) that the growth and development of a State depends largely on the legitimate tasks performed by the State functionary and the Citizens in any countries will determine how semblance of orderliness will be achieved.. In addition, in every human society, it is expected that State functionary are established by constitutional and historical laws to provide basic ameliorative incentives such as provision employment opportunities, security to lives and properties among others while the citizens are expected to participate in democratic processes as means of obeying national calls and pay tax regularly to facilitate semblance of orderliness. The outcome of the secondary publications shows that over relying on the Nigerian Security personnel cannot solve the societal problem and challenges we are currently facing now. The primary data collected from the thirty-eight (38) respondents are interpreted are stated below

\section{Respondent $1-$}

We are all Nigeria we fully understands that political culture we operate in this country. Let say the truth how many thugs can the police arrest during election. This 
people are more powerful and belong to the ruling political class. If any police officers are wounded during such period that is just the end of his contribution toward safety and security of people in his or her country. Most of these thugs are well known and nothing can be done. Even if they are arrested after the election the political class will fly them out of the country and later come back and they will be awarded several contract. The Nigeria Police are normal human beings like any other Nigerians, who will care for their families after they are killed in the process of securing lives and properties of the people. Please to me Nigeria Police are trying in the area of their duties but there is always room for improvement despite the fact they still need training to advance their core duty. I cannot really blame them but some of them are not meant to be recruited into the security position because of the practical knowledge and my empirical reason that I experienced during the last election in Nigeria

\section{IDI/Man//Yoruba/37yrs/ Ere-Akari Estate/Ward G//2020}

Respondents 2-------

"The people that lived in Oshodi-Isolo are living witness to what am trying to say. You are free to interview others from my area so that you have people from different ethnic groups that lived here will want to say concerning the question you asked me now. First and foremost we are still behaving as if we are illiterate as at this time and level of globalization and modernization. Everybody is looking for what to do and how to do and achieve it. How do you want me to believe that the problem of the past is what is still affection our political process or causing political problems in Nigeria. Although, Professors can be saying that in schools so that our children can have access to the knowledge of the past and present while in schools learning about the history of their home land. Please go and find out this that an Igbo man believes in reality on ground not sorry of the past. The political process of the past is full of violent activities; we know but not as what we are experiencing in Nigeria now Most of the political parties have or organized political thugs that will fight for them and they are paid for it. Once these thugs are arrested in some minutes you will be surprise to see them again in the larger society living in big houses and travelling up and down to different countries in the name of thuggery. How and what messages are we passing on to the next generation or what kind of leaders are we building for the future. Every political parties have their organized political thugs apart from the state security personnel. Please look at the Nigeria Government in all areas of elected or elected positions; you will be surprise on the numbers of thugs on their paying lists in the country"

\section{IDI/Woman/Yoruba/29yrs/Mafoluku Street/Ward D/2020}

The result gathered from the findings deciphers that a lot is expected to be done in order to ensure safety of lives and properties in Nigeria. For example, the primary data collected from the respondents shows that the primary data collected from the thirty-eight (38) respondents indicated that $36(94.7 \%)$ of the respondents were of the view that the work of security in Nigeria should be the primary duty of every Nigeria. That we should always be ready to assist the Nigeria Police in term of useful information that will help them in solving societal related problem while $2(5.3 \%)$ of them avers that the Nigeria Police are not what reporting the issues of crime or political violence to because they are not always in charge or not in full control of political crisis in Nigeria. No wander Agbu (2016) asserts that the political process in Nigeria needs to be thoroughly studied because of the volatile nature and serious socio-economic and political implications associated with the practices in Nigeria 


\section{Question 4----What is the social cost of political insecurity among various institutions in the study locations?}

The social cost of any violent activities should not be underrated because those that are affected are still facing the trauma till date, living hopeless because of vandalisation of properties worth millions while others are dead. Several publication articulated for the development of this research deciphers that the implications or aftermaths of political violence is always disastrous compared with the selfish advantages derived by the political elites in Nigeria. Several daily reports before, during and after election shows that the foxes are mostly affected by the political violence while the initiators of the violence are less affected with their various families in diaspora. The social and economic lost and implications of the political violence perpetuated by the youths mostly affect the poor, needy and less advantage members of the society compared with the magnitude of the problem of violence faced by the political leaders. Nayak (2014) argued that the Nigerian Youths are labeled as the crime prone segment of the country, who was employed by the political elite to clandestine political process to gain advantages for their selfish interest. The secondary data collected through the use of publication corroborate with the findings of the primary data collected at the study site. Thus, the response of the members of the participants were interpreted as follows

Respondent $1-$

I am a Yoruba man and I will like to explain this question from Yoruba adage that says whoever shoes pains. If you have ever faced or experienced war you will never pray for it. I have one time experienced political violence in Oshodi-Isolo here and I loss a friends and a brother in the fights who are not even politicians but they decided to vote for the right candidate before sporadic shooting occurs and claim their lives. Do I want to talk about properties set on fire or cars vandalized because of election or political process? Election or political process in Nigeria is not encouraging especially in Lagos state. See the ways and manners at which thugs dominated everywhere in Lagos doing all sorts of things and getting away with it. I don't think the Nigeria Government is not connected with the ways they make uses of the thugs to gain freedom and access to their mandate. If not those thugs are not spirit but normal human beings that reside in our mist and doing evil in our mist without reporting them to the security officers. Even when you report the fear of attack after their release is also very high. This is one of the major reasons for keeping silence about reporting them to the Nigeria Police. Do we know whether they (security) apparatus walk with the state security

\section{IDI/Man//Yoruba/37yrs/ Ere-Akari Estate/Ward G//2020}

Respondents2----

"Once these thugs state displaying their intellectual political thuggery ideology, people will run for their lives because I use to wander where they get the guns and other forms of weapons from. I use to run for my dear life because if you die you are on your own without any justice. Once they start it can result to loss of lives, vandalisation of houses and cars on the roads, stealing and snatching of gold and rape at the end of the day. My special advice to you in my area is that once they start (thugs) just move fast to a safe place before it get dark or else you will find yourself to blame.

\section{IDI/Man/Hausa/34yrs/Mafoluku Street/Ward D/2020}

The outcome of the research shows that out of the thirty-eight (38) participants at the field, $38(100.0 \%)$ of them sees the social and economic implications of the disastrous to human and economic development of the country. This is because innocent and honest Nigeria who 
came out to perform their constitutional rights and obligations were almost affected in the process of performing the right to vote and be voted for in Nigeria

The purpose of every interpretation of any research inquiry is to discuss the finding of the inquiry using the set objectives of the study as guide toward ensuring adequate discussion in line with the paper. Thus the first objective intends to find out the predisposing factors that lead to political insecurity in Nigeria. Thus, the submission of the scholars in reviewed in secondary source of gathering information is not quite different from what was discovered from the primary source of gathering information but an additional input was discovered. Thus, scholars argued and put forwards that there are several factors that can be held responsible for the prevalence of political insecurity in Nigeria ranging from poverty, unemployment, selfish interest but this research intend to add to existing knowledge by adding greed and lack of contentment to personal belongings. The second objective intend to find out how political party formation influence political violence during election among various political actors. The submission of scholar from secondary publication is a bit different from what is derived from primary source. Thus, scholar are of the view that most the political partied formed during colonial and pre-colonial period are based on ethnic formation, therefore, that is the more reasons for the political violence experienced all over Nigeria before, during and after elections. But the primary result shows that the history of the past should not remain as yardstick to judge the present situation. Thus, the submission of the people interviewed at the field shows that Nigerian government and the Nigeria citizens should seat round the table for corrections of the past. They added that most of the corrupt practices experienced today in Nigeria cannot be related to the colonial ideology. To them there is a need for reconstruction, restructuring and reconciliation of minds and thoughts so as to move the country forwards to be a better place for us. The third objective intends to what extent has the Nigeria Police strive to curb the situation of political thuggery in Oshodi-Isolo Local Government Area, Lagos. The findings derived from secondary publication complement with the primary information but still a bit differences. The information derived from publication from different scholars show that the Nigeria Police should not be totally blame from not been able to curb or control the political insecurity prevalence in Nigeria due to several factors ranging from lack of constant training, motivational incentives, delay in payment of salary and lack of ultra-modern equipment to fight against injustice in the country. The primary information validate the claim of the secondary scholars but moved a bit forward that despite the fact that they (Nigeria Police) cannot be totally blame for not be active in ensuring security of the state from the point the view of state failure. Thus, some of this officers need to be trained an equally retrained so as to have adequate commitment to security work. The last objective intends to know the social cost of political insecurity among various institutions in the study locations. The findings of the secondary information gathered from publications shows that the social and economic cost of political insecurity or violence has negative implication on individuals, family, industries and society at large because increase in political insecurity will lead to psychological trauma, retrogressive economic development, civil unrest, lost of hope in nation building and bad international image among others. Thus, the primary information is of equal standard with what the respondents interviewed at the field said concerning the consequences of political insecurity where the respondents laments that political process or election in their locality is mostly deadly because large numbers of properties were destroyed, cars vandalized, houses burnt, belongings are snatched and all sort of harassment such as molestation and rape were equally experienced 


\section{CONCLUSION AND RECOMMENDATION}

The research inquiry is concluded on the fact that the research is designed to find solutions to the problem emanating from the course of study. Thus, it was discovered at the end of the research that there are external and internal factors that can be held responsible for the cause of political insecurity in Nigeria. Thus, to some people the causes are external such as poverty, unemployment, selfish interest from the leaders, lack of quality acquisition of education but in advance internal causes such as greed from the part of the youths, love for money and get rich syndrome are factors that must be recognized in the research inquiry

The second conclusion was derived from the question that intends to know how political party formation influence political violence during election among various political actors. The question and finding of the study lead to subjective conclusion that is subjective. To some the colonial history and Amalgamation history cannot be underrated in the political development of the Nigerian leaders while others disagree to the statement of historical records. To them the colonial history should not show at this level of globalization because such history should be considered as things of the past. To them the Nigerian Government are hiding under the umbrella of the colonial master to actualize their selfish interest at the detriment of the general interest of the people that vote them into position of power

The conclusion of the third research inquiry is derived from the question which intends to know the extent in which Nigeria Police strives to curb the situation of political thuggery before, during and after election in Oshodi-Isolo Local Government Area, Lagos?. The conclusion derived from this question is also subjected to diverse interpretations. To some the Nigeria Police cannot be totally blame for the level of insecurity experienced in the country because of failure of the state functionaries in provide security amenities to the Nigeria police in term of fighting against injustice. Others claimed that the Nigeria police are full of corrupt practices which are stipulated and violate the security code of conducts. For example, is it the Nigerian government that gave them the authority to extort people of commercial drivers on the road instead of fighting against injustice they are more interested in the monetary aspect of the society?

The last conclusion is derived from the question that intends to know the the social and economic implications of the political insecurity experienced in the study location. The research was concluded that political violence will result into political insecurity if not properly managed in the society. This is because when political violence occurs in any society it will degenerate to civil unrest, psychological trauma, loss of hope among society members, retrogressive economic development and bad international image among the Africa continent and other continent in the world

The recommendations of this study can be derived from both internal and external condition. Thus, the external conditions are deliberated and discussed by scholars all over Africa because large numbers of African leaders are selfish in nature which is what Thomas Hobbes said and proclaim in the state of nature. More so, they are equally full of ego because the moment they attain the position of authority they become untouchable in the society. It is on this ground, the following workable recommendations are stated

a) Nigerian youths especially youths that reside in Oshodi-Isolo need strong political socialization so as to be able to establish strong political culture. Thus, the political culture established in the study site is of survival of the fittest or do or die political culture. Thus, public political awareness needs to be put in place so as to seek the future of the incoming generation. Large numbers of these youths are socialized into wrong political orientation based on the money they received from the political gladiators in the study site. Therefore, there is a need for youths to liberate themselves from the concept of been used as slave or political thugs by the political elite to achieve 
their aims by killing the right person that can lead the study site towards progressive development

b) Nigerians should purge themselves away from the ideology of referring the security of the nations into the hands of the Nigeria Police alone. It is high time we all need to know that the security of the nation is not just in the hand or jurisdiction of the police, it involves every Nigerians because they police cannot do it alone without the useful information that we supply. Most of these youths that carried out this violence lived within our community, therefore we need to report and cooperate the Nigeria Police to fight this menace

c) The introduction of community policing such as Police Community Relation Committee, integration of Operation Amoteku, vigilante, Odua People congress, Bakkassi among others should be employed to fight and support the operation of the Nigeria Police in achieving the security to lives and properties of the people that votes and those voted for in the study site

d) The Nigeria Police need to be constantly train, motivated and enjoy national insurance so that the high level of commitment can be derived from their jobs. More so, more Police are needed in the security area of Nigeria because as at 1988, the total statistic of a police man to secure the citizens is ratio1 to 514 as at then talk less of what we are experiencing now in Nigeria. There is a need for the Nigeria government to employ more police to ensure the safety of lives and properties of the people

e) In the Nigeria, one of the worst scenarios that hamper the Nigeria Democratic or electoral system is anchored on political godfathers. These political godfathers are one of the sources that destroyed Nigerian political process due to the fact that they capitalized on the problem facing the Nigerian youths such as poverty, unemployment among others. Thus, if they did well while in office they need not to use money to attract the youths if no hidden agenda. The youths should observed vividly and get informed about what most of them have done while in office if good or bad before they accept them as positive godfather in any wards or constituency

f) The political elite should look for the best means of educating the youths in Nigeria through different dimensions such as organized local discussion in the grassroots, enlighten youths through organized sport competitions, organized talk-shows or interschools debate, create a strong innovative skill learning workshops among others were the youths can gathered and take the advantage to spread the importance of be a patriotic citizens rather than be used as agent of political violence in the country

\section{REFERENCES}

Abdullahi, S.,A., Mohammed I. Z., \& Casey, C. (eds) (2011). Studies in Cultural Sociology. Foludex Printers, Ibadan Nig.

Aborisade RA. (2016). Crime and Delinquency; A Sociological Introduction. Ibadan. Ibadan University Press

Agbaje, A \& Adejumobi, S. (2006). 'Do Votes Count? The Travails of Electoral Politics in Nigeria. Africa Development 31(3)pp 12-32

Agbu O. (2016), Impact of the Election on Governance; Lesson Learned. Election and Governance in Nigeria Fourth Republic. Dakar CODESRIA pp9-25

Ajayi R and Fashagba J.O. (2014), Nigeria; A century of Rough Journey.in R Ajayi anf J.O Fashabga (eds) Understanding Government and politics in Nigeria. Pp 1-22. Landmark University Omu-Aran. Kwara State

Alubo, O. (2012). Sociology: A Concise Introduction. Jos, Nigeria: Ichejum. Press Ltd. 
Edet L (2015), Electoral violence and Democratisation process in Nigeria; A reference of 2011 and 2015 general elections. ACTA Universilatics. Danubius Administratic 7(1) pp 43-53

Ejike, S. (2014) “Additional Polling Units: INEC's Plan to Rig 2015 Elections, Southern Assembly Alleges.” Nigerian Tribune, September 10. Available at:

http://www.naijaheadlines.com/agency/tribune/20140909/654145/additionalpollingunits-inec-s-plan-to-rig-2015-elections-southern-assembly-alleges

Ewetan OO, Urhie E. (2014), Insecurity and Socio-economic Development in Nigeria. Journal of Sustainable Development Studies. 5(1)40-62

Fabiyi, O. (2014). After Collecting their N24m, PDP Rejects two Presidential Aspirants.Punch, 29 October. Available from: http://www.punchng.com/news/aftercollecting- their-n24m-pdp-rejects-twopresidential-aspirants/.

Gaal H.D and Afrah N.A. (2017), Lack of infrastructures; The impact on Economic development as a case of Benadir Region and Hic-Shabelle Somalia. Developing Country Studies 7(1)pp10-32

Haralambos M, Holborn M. (2013), Sociology Themes and Perspectives. India. Harper Collins Publishers

Haruna, A Jumba, A.H. (2011). Politics of Thuggery and Patronage in the North Eastern Nigeria. Journal of Academic Research International, 1(1), 111-119.

Herskovits, J. (2012). In B. a. Sule (Ed.), Popular Participation and Democrazation in Nigeria Under Youth Republic. ARADA.

Igbo, H.I \& Ikpa, I. (2013). Causes, Effects and Ways of Curbing Youth Restiveness in Nigeria: Implications for Counseling. Journal of Education and Practice, 4(6)pp 131137.

Jega, A M. (2012) “The Electoral Process and Security Sector Synergy” A Paper Delivered to EIMC 6 Participants of Institute for Security Studies (ISS). Abuja. August 21

Jega, A.M. (2015b) Election Postponement Speech. Pulse, 7 February Available from: $<$ http://pulse.ng/politics/2015elections-read-full-text-of-jega-s-electionpostponementspeech-id3466565.html>

Kasali MA (2010), Basic Security and Security Threats. National Open University of Nigeria

Merton, RK. (1968). Social Structure and Anomie. American Sociological Review 3(5)pp 672-682.

Muhammad, H. (2014): Popular Participation for Sustainable National Democratic Development. In Bello, S. and Yusuf, M.M (Eds) Popular Participation and Democratization in Nigeria under the Fourth Republic. Zaria: Africa Research and Development Agency (ARADA)/Ahmadu Bello University Press Limited.

Musa .Y. (2015). Party Politics, Electoral Crisis and Democratic Consolidation in Nigeria, International Journal of Academic Research and Reflection, 3(1)

NBS \& Ministry of Youth and Development. (2013). National Baseline Youth Survey Report. Abuja. NBSSC/10533:2011.

Ninalowo AMA, Badru F, Akinyemi R. (2010). An Interdisciplinary Discourse on the Human. University of Lagos Press

Odebode, N., Alechenu, J., Obe, E., Oluwole, M.J., Affe, M., Chiedozie, I., Ogundele, K. and Nwogu, S. (2015). PDP Panics over High PVC Collection in APC Strongholds. Punch, 11 January. Available from: <http://www.punchng.com/news/pdp-panicsoverhigh-pvc-collection-in-apc-strongholds/> 
Offiong A.V., Jimoh, A., Alhassan, A., Bivan, M., Ahmadu-Suka, M., Adibe, T. and Akinyemi, A. (2015). Nigerians in last minute rush for PVCs. Daily Trust, 7 March. Available from: <http://www.dailytrust.com.ng/weekly/index.php/top-stories/19234nigerians-in-last-minute-rush-for-pvcs $>1$

Ojukwu, C and Oni, E. (2016). Ethnicity and Political Transition Programmes in Nigeria, 1960-1999. Journal of African Elections, Vol. 15(2)

Okafor JP (2012), Description of Strategies for achieving National Stability in Nigeria Society as expressed by Youths and Professionals in the North-central Nigeria. Nigerian Journal of Sociology of Education 6(1)78-85

Olutayo AO, Akanle O (2013). Sociological Theory for African Students. Ibadan. Ibadan University Press

Oni, E.O (2014) Democracy and the Challenges of Consolidation in Nigeria's Fourth Republic. Ibadan Journal of the Social Science. Vol. 12(2).

Oni, M.A (2016) Elections and Electoral Processes. In Yagboyaju, D.A; Ojukwu, C; Salawu, M and Oni, E (eds) Fundamentals of Politics and Governance. Lagos: Concept Publications Ltd

Ritzer G. (2012) Modern Sociology Theories. London. McGraw-Hills Publishers

Snapps, O.J. \& Hamilton, D.I. (2011). Youth Restiveness and Industrial Distruption in the Niger-Delta. American Review of Political Economy, 18-32.

Yagboyaju, D.A (2011). Nigeria's Fourth Republic and the Challenge of a Faltering Democratization. African Studies Quarterly, Vol 12(3)

Yusuf, A.Y. (2013). Nigerian Federalism: Implication and Option for Sustainable Development. International Journal of Advance Research in Public Policy, Administration and Development Strategies. 1(1)pp 85-92 